Reprod. Nutr. Dévelop., 1981, 21 (6A), 885-899.

\title{
Importance of the abomasum in digestion in the preruminant calf
}

\author{
par P. GUILLOTEAU, R. TOULLEC, P. PATUREAU-MIRAND *, J. PRUGNAUD * \\ with the technical assistance of G. ABELARD, Françoise BARRE *, S. BOUSSION, Marguerite BEAU- \\ FILS, J. LAREYNIE, Monique LESNE, Y. MANIS, Marie-Claude VALLUY* \\ Station de Recherches Zootechniques, I.N.R.A., \\ 65, rue de St-Brieuc, 35042 Rennes Cedex, France. \\ * Laboratoire d'Etudes du Métabolisme Azoté, I.N.R.A, \\ Theix, 63110 Bequmont, France.
}

Summary. Substituting the skim-milk in milk replacers by other sources of protein increases the rate at which lipid and protein are emptied from the stomach. As a result, the digestive and metabolic utilization of these components might be unfavorably affected due to their more brief contact with abomasal digestive secretions and to their massive arrival in the duodenum. The aim of this experiment was to study the respective effects of the latfer two factors.

Seven preruminant calves, fitted with a catheter in the proximal duodenum, were given two diets having very different kinetics in respect to gastric emptying. The protein in these diets was supplied either almost solely by skim-milk powder (control feed) or mainly by a partially hydrolysed white fish concentrate (fish feed) (table 1). The milk replacers were either ingested by the animals or infused slowly or quickly into the duodenum to simulate previously observed gastric emptying rates (Guilloteau et al., 1975) for protein in two diets similar to those used in the present experiment.

Bypassing the mouth and the abomasum did not seem to have any significant effect on animal health, particularly as far as the frequency of diarrhea was concerned (fig. 1). The apparent digestibility of each diet decreased when that diet was infused into the duodenum at the gastric emptying rate of its protein (slow infusion of the control diet, quick infusion of the fish diet) (table 2) ; infusion at a higher rate (quick infusion of the control diet) increased this effect, while infusion at a lower rate (slow infusion of the fish dief) suppressed it. This decrease in apparent digestibility was more marked for lipid and minerals than for protein.

The slow infusion of the fish diet had little effect on faecal amino acid composition (table 4). On the other hand, rapid infusion of the control diet seemed to cause a decrease in the relative proportion of microbial protein in favour of some milk protein fractions (serine and glutamic acid-rich phosphopeptides of $\alpha_{s 1}, \alpha_{s 2}$ and $\beta$ caseins).

Blood free amino acid levels, measured during simulation of the gastric emptying of each dief, were similar to those observed during ingestion (table 5). These levels were higher when both diets were infused quickly than when they were infused slowly.

In conclusion, the digestion of protein, and especially that of lipid and minerals, as well as the metabolic utilization of amino acids, is highly influenced by the time spent in the abomasum and by the rate of arrival in the duodenum. 


\section{Introduction.}

When the skim-milk in milk replacers for the preruminant calf is substituted by other protein sources, the lipids and proteins are rapidly emptied from the stomach, mainly because coagulation does not occur. The intensity of this increase in the emptying rate depends on the origin of the protein and on its technological treatment (Guilloteau ef al., 1975, 1979 ; Ternouth and Roy, 1973). These changes may unfavorably affect the digestive and metabolic utilization of lipid and protein which have a shorter contact with digestive secretions in the abomasum and arrive massively in the duodenum.

The aim of this experiment was to study the respective effects of the latter two factors, using diets having very different kinetics of gastric emptying and whose arrival in the duodenum could be slowed down or speeded up by infusion with a peristaltic pump. The methodology and the preliminary results of this work have been already published (Guilloteau, Toullec and Patureau-Mirand, 1979).

\section{Material and methods.}

Animals and diets. - Seven male Friesian calves were fitted with a catheter in the proximal duodenum then put into balance crates. They were fed two milk replacers in which the protein was supplied either almost solely by skim-milk (control diet) or mainly by a partially hydrolysed white fish concentrate (fish dief) (table 1). The experiment began when the animals were at least one month old. The two diets were offered in two meals per day (58 $\mathrm{g}$ of dry matter $/ \mathrm{kg}$ of live weight ${ }^{0.75} / \mathrm{day}$ ).

Experimental design, measurement, analysis and calculation. - The diets were either ingested by the animals or infused slowly or rapidly by peristaltic pump into the duodenum. When infusing, we simulated the gastric emptying rates previously observed (Guilloteau et al., 1975) for the protein of two diets very similar to those used in the present experiment. The details of this methodology have already been reported (Guilloteau, Toullec and Patureau-Mirand, 1979). The six possible treatments (2 diets $\times 3$ feeding methods) were used in a different order for each animal ; however, only two calves retained their catheter long enough to receive all of them. A minimum 9-day interperiod was used to adapt the animals gradually to each new treatment.

During each period of measurement ( $2 /$ calf/treatment), the proposed and refused diets, as well as faeces and urine, were weighed and sampled for 5 successive days. Total nitrogen, phosphorus and calcium were assayed in all the samples obtained. Dry matter, lipid and mineral contents were determined in samples of the diet and the faeces. The amino acids were assayed in the faeces of calves A and B collected when the control diet was infused rapidly and the fish diet was infused slowly. Blood samples were taken from the jugular vein $4 \mathrm{hrs}$ after the beginning of the morning meal the last day of each period. Glucose and urea were assayed in all samples; free amino acid levels were measured in one mean blood sample per treatment, obtained by grouping together the samples of all the calves tested. The analytical methods have been des- 
TABLE 1

Diet composition

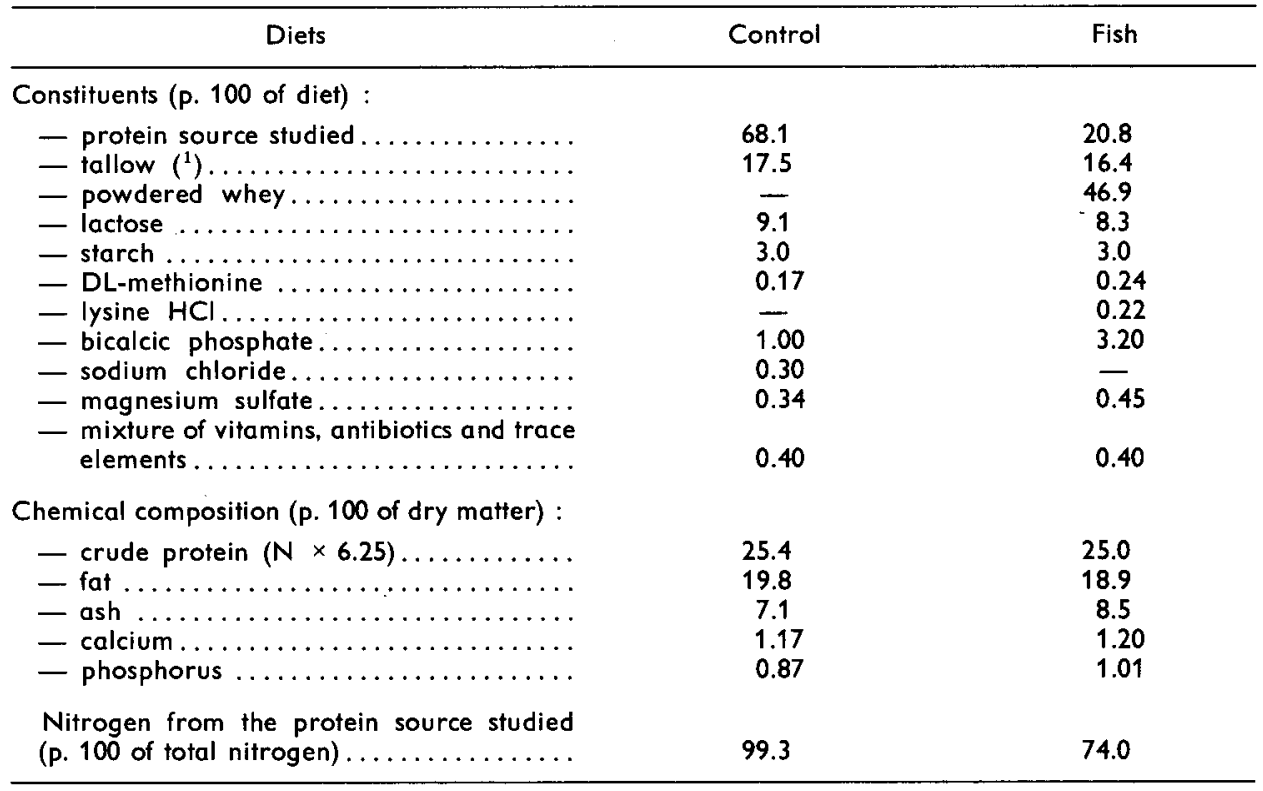

( ${ }^{1}$ ) The tallow was incorporated into concentrated skim-milk (control diet) or whey (fish diet); the fwo liquid mixtures obtained were then homogenized and spray-dried.

cribed previously (Guilloteau ef al., 1977 ; Patureau-Mirand et al., 1974). Protein amino acid compositions were compared by calculating the $\chi^{2}$ distance and by using correspondance analysis (Guilloteau ef al., 1980a, b).

\section{Results.}

Intake, growth, health status. - When given by ingestion, both diets were completely eaten. When gastric emptying was simulated, the true amounts infused were similar to the planned ones (Guilloteau, Toullec and Patureau-Mirand, 1979).

Animal growth was satisfactory, except with rapid infusion of the control diet. Feed efficiency was much less satisfactory with rapid infusion of the control diet and ingestion of the fish diet (table 2).

The calves presented no health problems during the experiment. The classification of Blaxter and Wood (1953), based on faecal dry matter levels, was used to characterize the faecal status (fig. 1). There were very few days on which the calves had diarrhea. Faecal status did not differ among the ingested diets; however, when the two diets were infused into the duodenum, faecal dry matter content was lower with the fish dief than with the control diet. There was a much higher frequency of normal status with rapid than with slow infusion. 


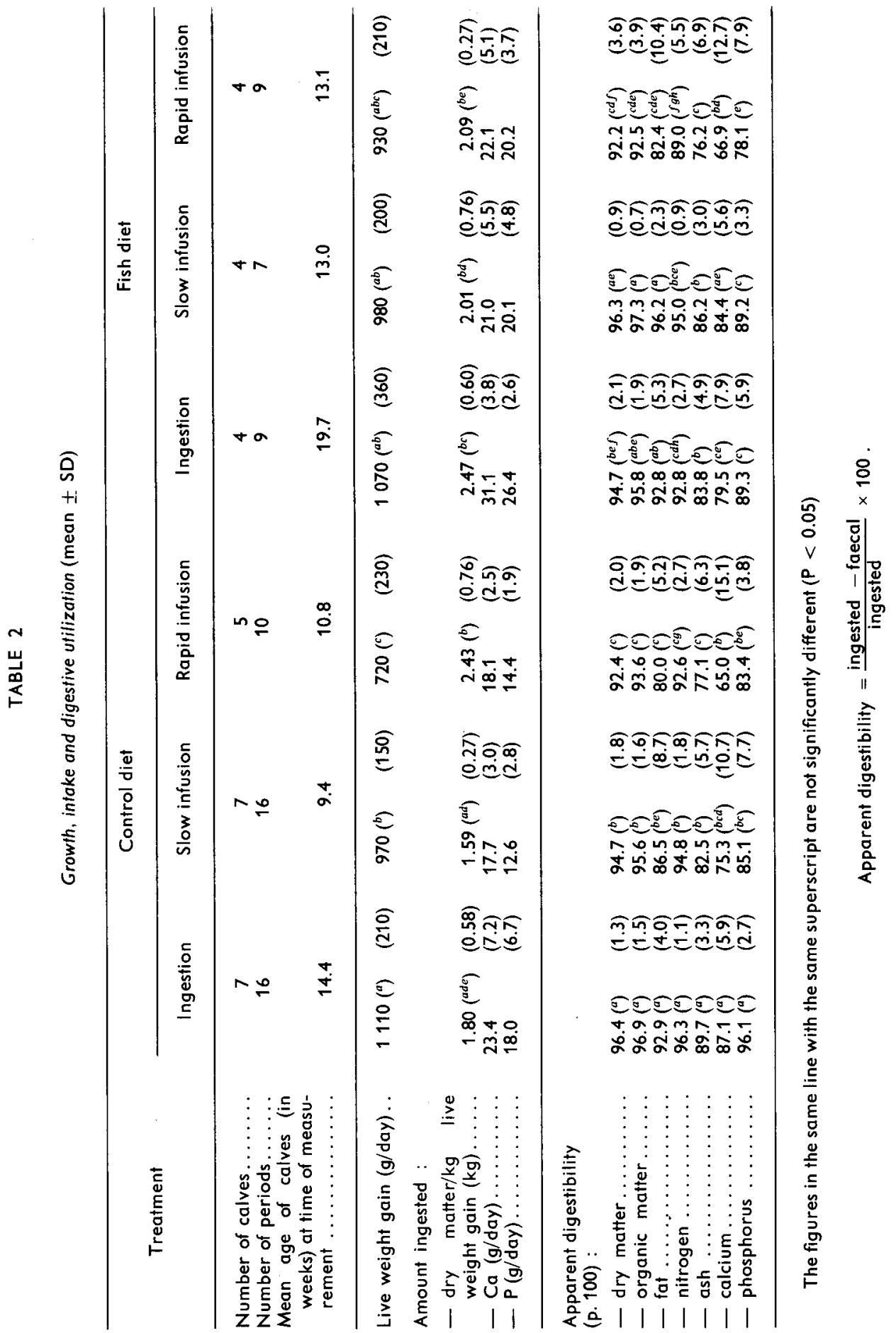




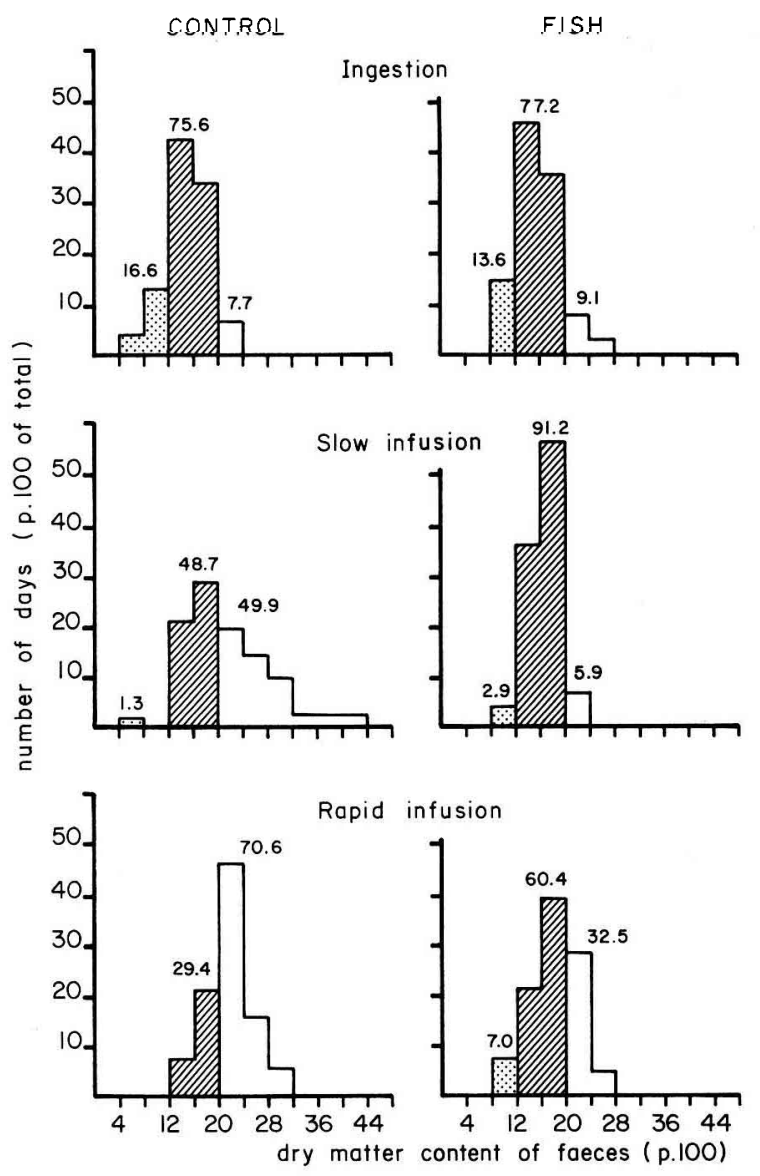

diarrheic foeces loose foeces $\square$ normal foeces

FIG. 1. - Distribution of dry matter content of foeces (p. 100 of sampling days).

Effect of previous treatment. - The results for each animal submitted to at least 2 out of 6 treatments showed no particular influence of the preceding treatment(s).

Digestibility of the diets (table 2). - When the control diet was infused slowly into the duodenum instead of being ingested, its apparent digestibility decreased significantly ; this effect was more marked for lipid, minerals, calcium and phosphorus than for nitrogen. Except for calcium and phosphorus, digestibility was still significantly lower when the diet was infused rapidly.

When the fish diet was infused slowly, its digestibility was not significantly modified. As compared to ingestion, rapid infusion caused a significant decrease in the digestibility of lipid, minerals, calcium and phosphorus; the differences with slow infusion were greater and were all significant. 


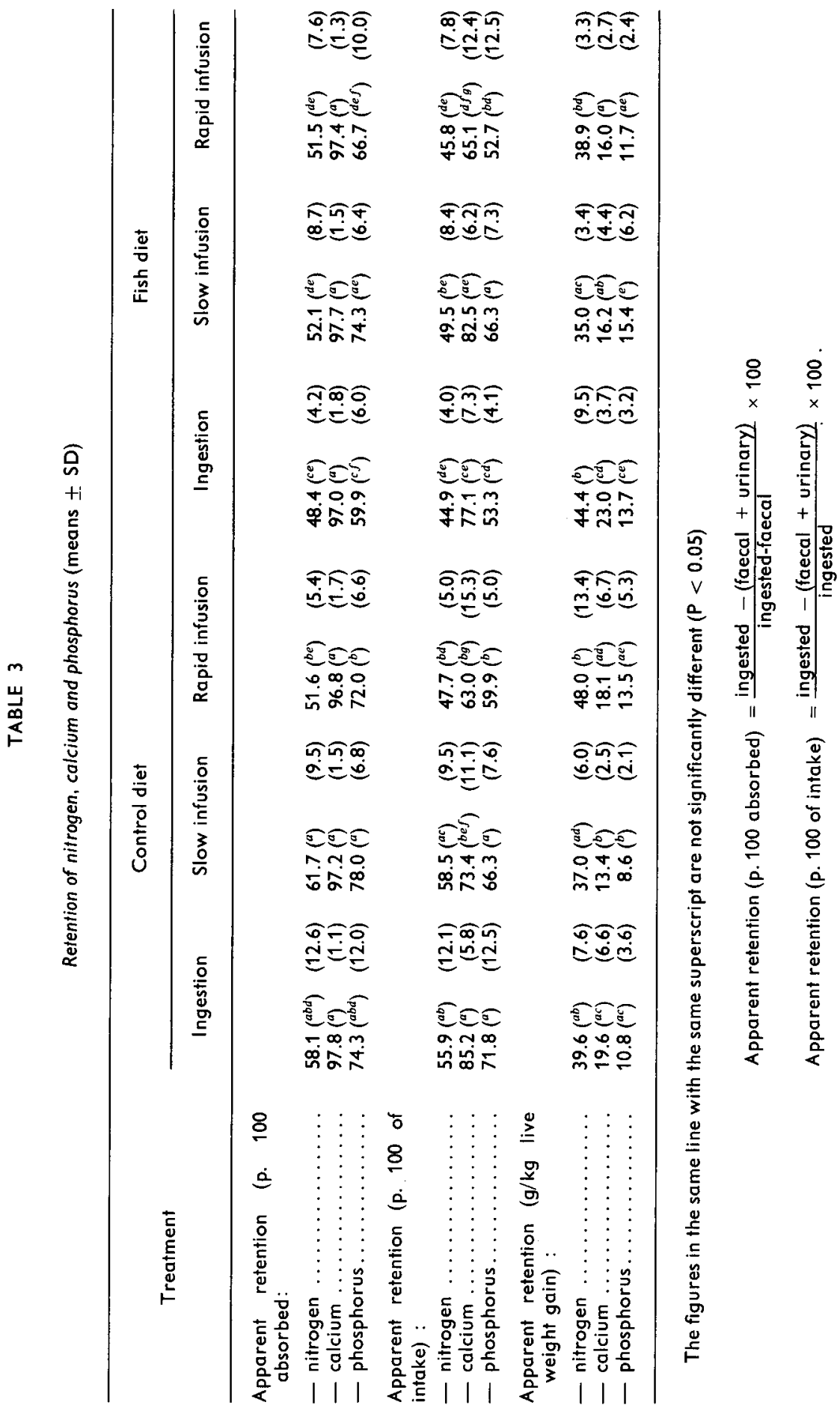




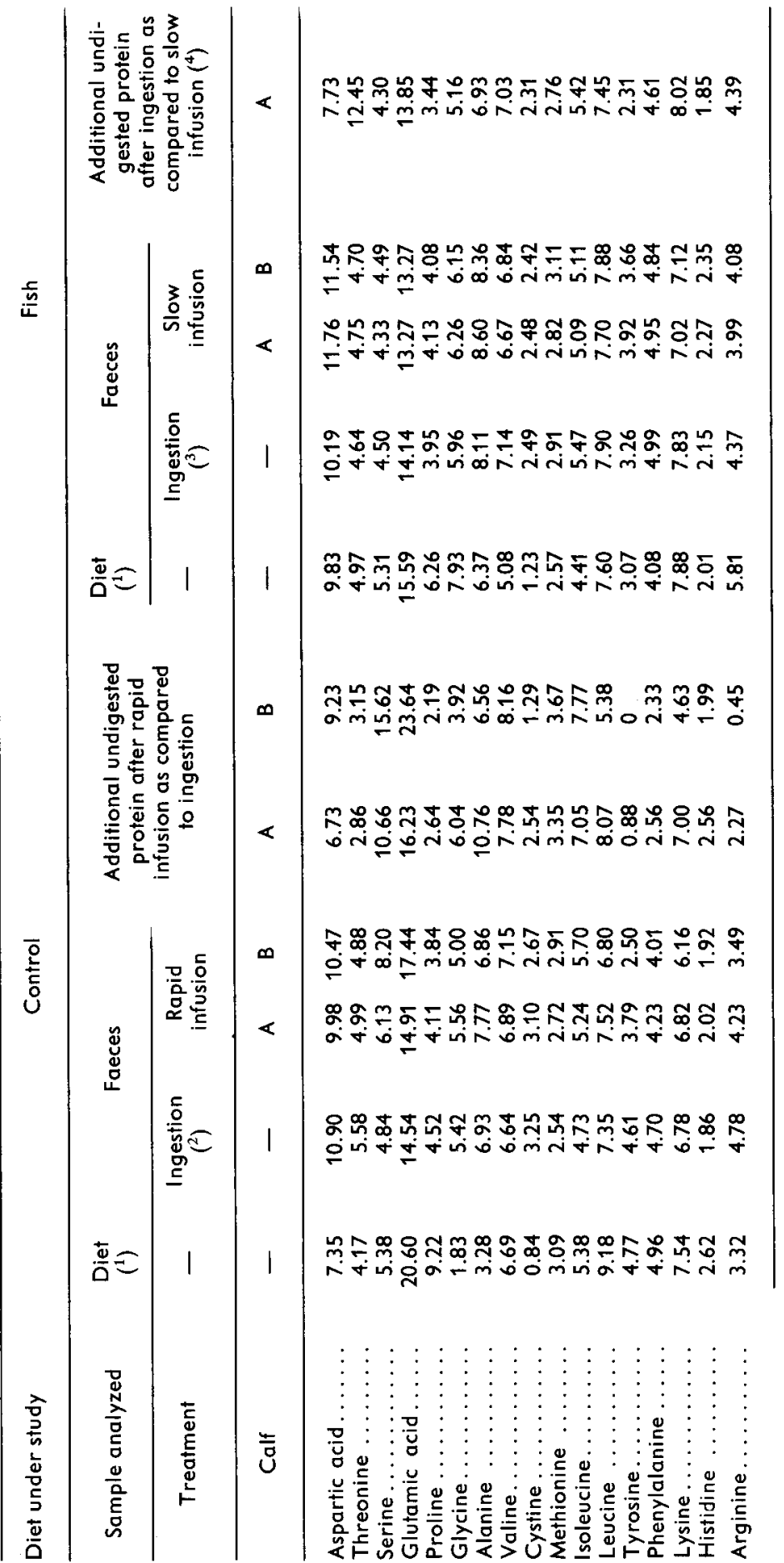

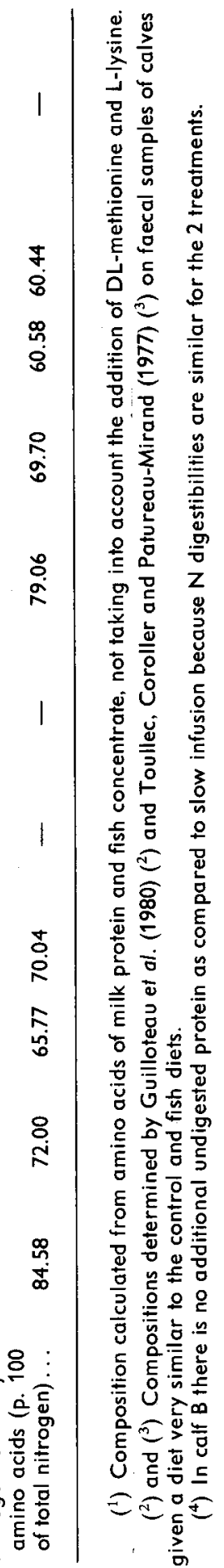


When ingested, the control diet showed higher digestibility than the fish diet; the differences were significant for dry matter, nitrogen, minerals, calcium and phosphorus. The situation was the reverse with slow infusion : the digestibility of nitrogen, minerals and phosphorus was then significantly higher with the fish than with the control diet. There was no significant difference between the two diets when they were infused rapidly.

Amount of nitrogen, calcium and phosphorus retained (table 3). - The percentages of calcium and phosphorus intakes that were retained decreased significantly when the control diet was infused slowly or rapidly instead of being ingested. The percentages of nitrogen and phosphorus intakes that were retained were lower with quick than with slow infusion. With the fish diet, the percentage of phosphorus intake retained was higher with slow infusion, and that of calcium lower with quick infusion.

The percentages of nitrogen and phosphorus intakes which were refained were higher with the control than with the fish diet when the diets were ingested. Only the values for nitrogen remained significantly higher with the control diet when infused slowly; they were no higher with rapid infusion.

Amino acid composition of faeces. - When the control diet was infused rapidly, faecal amino acid composition varied with the individual, while when the fish diet was infused slowly there was practically no individual variation (table 4 ) : the $\chi^{2}$ distances between the faeces of animals $A$ and $B$ were $38(P<0.01)$ and 1 , respectively.

When the control diet was infused rapidly, the faecal amino acid composition of calf $A$ was close $\left(\chi^{2}=17\right)$ to that of calves eating a diet of very similar composition (Guilloteau ef al., 1980a). On the other hand, the amino acid composition of calf $B$ faeces deviated considerably $\left(\chi^{2}=81 ; P<0.001\right)$ due to its higher levels of serine, glutamic acid, valine, isoleucine and lower levels of threonine, leucine, tyrosine, lysine and arginine.

When the fish diet was infused slowly, the faeces of calves $A$ and $B$ all had an amino acid composition $\left(\chi^{2}=8\right.$ and 11$)$ very close to that of calves eating a diet of similar composition (Toullec, Coroller and Patureau-Mirand, 1977).

Diet-dependent differences were also small, whatever the method of administration since the $\chi^{2}$ values, calculated by comparing the faeces resulting from the control and the fish diets, varied between 25 and 31 . Only calf $B$, rapidly infused with the control diet, showed faeces which deviated from those obtained with the fish diet $\left(\chi^{2}\right.$ ranging from 88 to 97 ).

All these differences were visualized by correspondance analysis (fig. 2) which also showed that the amino acid composition of the faeces more closely resembled that of faecal bacteria than that of the diet or the ileum digesta of the milk-fed calf which are rich in endogenous protein (Guilloteau et al., 1980a).

Levels of plasma glucose and urea and of blood free amino acids. - Plasma glucose and urea varied little with the treatment; only the glucose level was lower when the control diet was infused quickly.

Blood free amino acid levels were hardly modified when the control and fish diets were infused slowly or quickly, respectively, instead of being ingested. On the contrary, these levels increased sharply when the control diet was infused rapidly and decreased when the fish diet was infused slowly. 


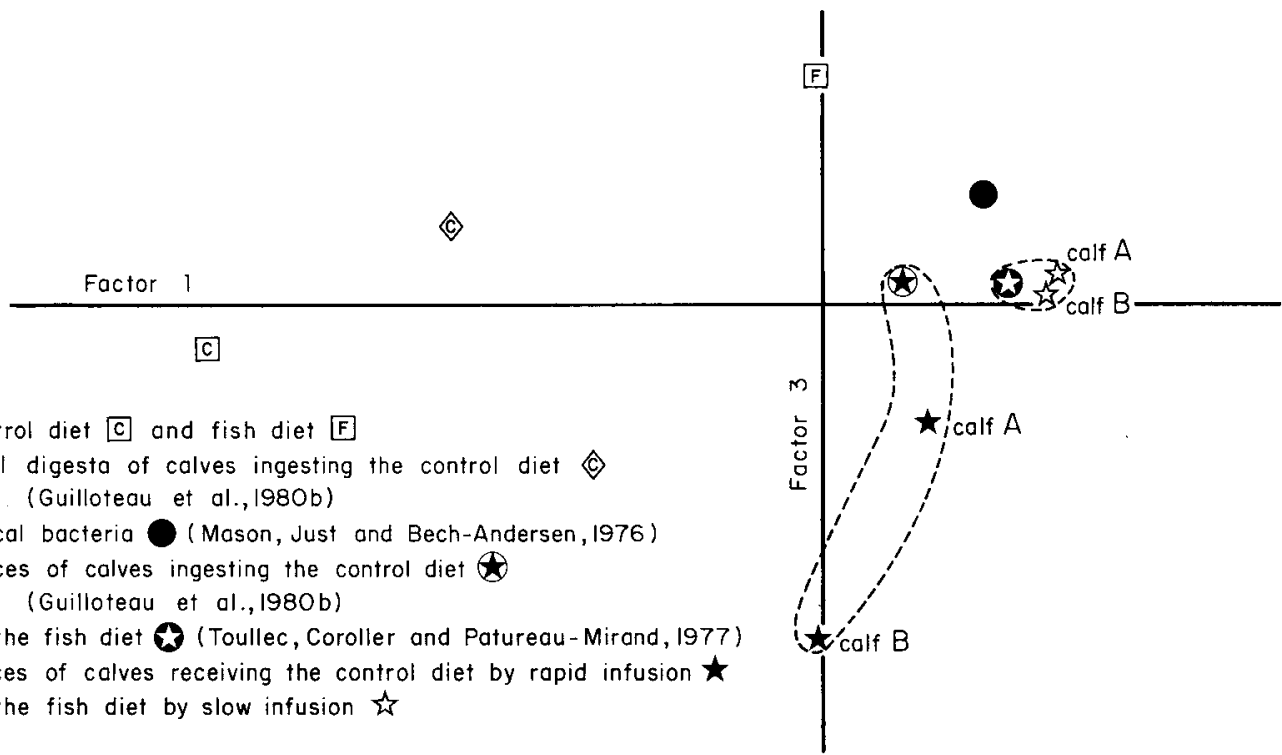

FIG. 2. - Comparison of amino acid composition (p. 100 of the sum of assayed amino acids) of different proteins. Diagram shows data on two main correspondance analysis axes ( 1 and 3 ).

Blood threonine, serine, asparagine, citruline, glycine, alanine, methionine, ornithine and lysine were lower with the control than with the fish diets when they were ingested; the same was true for the total essential amino acids and for the sum of all the amino acids. When the diets were infused slowly, all blood amino acid levels, except those of glycine, methionine and phenylalanine, were lower with the fish diet. When the diets were infused quickly, the total essential amino acid level and that of all the amino acids were slightly higher with the fish diet ; this was mainly due to threonine, glycine, alanine, methionine, lysine and arginine.

\section{Discussion.}

The experimental design used in this study required the use of several classical techniques : duodenal infusion, balance measurements, blood parameters. However, the method of infusing continuously, and not by synchronized bursts, is criticizable because it might modify the digestive processes. Moreover, the characteristics of duodenal digesta (e.g. acidification, dilution) and the neurohumoral regulation afferent to the abomasum and the duodenum (e.g. effect of gastric and duodenal repletion, secretion of digestive hormones) were probably not rigorously respected (Bell, 1979). Nevertheless, these changes were palliated by the fact that half the water given was ingested normally when the milk-replacer was infused into the duodenum.

Bypassing the mouth and gastric compartments did not seem to have much effect on the health status of the animals, particularly as concerned the frequency of diarrhea (fig. 1). On the contrary, faecal dry matter level was higher when the diet was infused. 


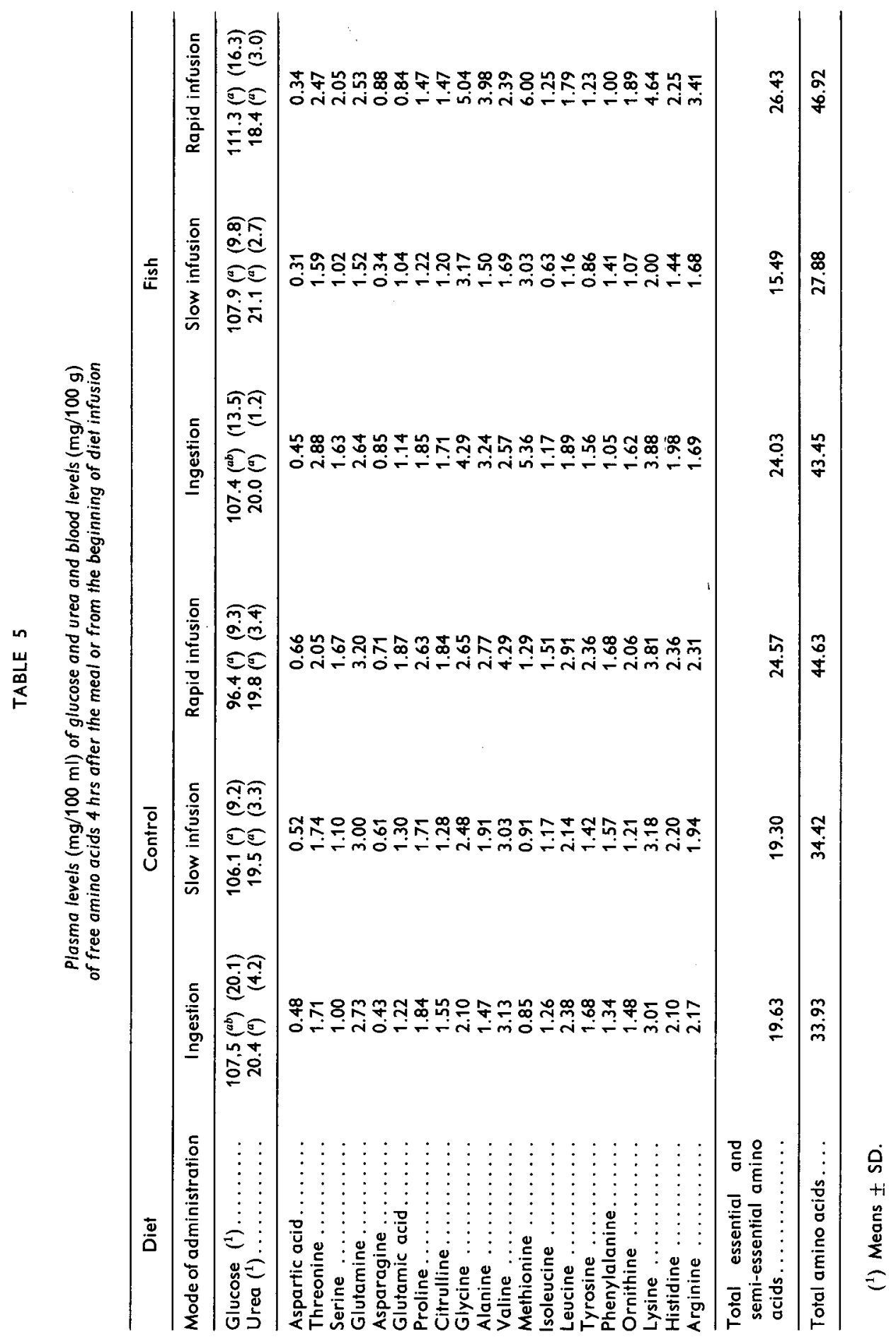


This may be explained in two ways. First, the duodenal aqueous phase occurs later with slow infusion than with intake; secondly, the lower digestibility of calcium and lipid, caused by slow or rapid infusion of the control diet and by rapid infusion of the fish diet, might make the faeces more consistent (Paruelle, Toullec and Mathieu, 1973).

The apparent digestibility of each diet decreased when the diet was infused into the duodenum at its gastric emptying rate for protein (slow infusion of the control diet, rapid infusion of the fish diet) (table 2). Quicker infusion (control diet) increased that effect ; slower infusion (fish diet) cancelled it. Bypassing the abomasum (and/or the the mouth), and therefore probably reducing the time of diet contact with the corresponding digestive secretions as well as accelerating the arrival of the diet in the duodenum, a depressive effect on digestibility. This effect, more marked for lipid than for protein, may be due to triglyceride hydrolysis in the abomasum (Toullec and Felinski, 1971), as well as to the deleterious effect of massive amounts of little digested or undigested protein arriving in the duodenum. Indeed, when the diets were infused slowly, lipid digestibility was clearly lower with the control than with the fish diet whose protein had undergone previous enzyme hydrolysis.

There were probably also interactions between lipid digestibility and that of calcium and phosphorus due to the formation of insoluble compounds in the intestinal lumen between the calcium on the one hand and phosphorus and long, saturated fatty acids on the other (Toullec, Flanzy and Rigaud, 1968 ; Fakambi, Flanzy and François, 1969 ; Paruelle, Toullec and Mathieu, 1973). Thus, the digestibility of phosphorus, and especially that of calcium, were even lower than lipid digestibility when both diets were infused quickly and when the control diet was infused slowly (table 2). It is difficult to estimate the effect of the treatments on digestibility and on the percentages of calcium, phosphorus and nitrogen intake which were retained because the measurements were not all taken at the same mean age (tables 2,3); only the two infusion rates of the fish diet can be compared : rapid infusion had an unfavourable effect on the percentages of retained calcium and phosphorus.

Calcium refention is regulated in the intestine (Guéguen and Mathieu, 1962). Thus, when a calcium-rich diet is given, the apparent digestibility and the percentage of calcium intake which is retained decrease as the calf's age increases (Paruelle, Toullec and Mathieu, 1973) because the amount ingested usually augments faster than the amount retained. The decrease in calcium digestibility and percentage retained with slow and rapid infusion of the control diet, as compared with ingestion, was thus probably due to the treatment. The same is true of the fish diet when the results on rapid infusion are compared to those on ingestion. Apparent phosphorus digestibility changed in the same way as that of calcium. The high urinary phosphorus losses, particularly with the fish diet, were the result of a relative phosphorus excess as compared to calcium (Guéguen and Mathieu, 1962). Very high amounts of nitrogen, calcium and phosphorus were apparently stored per $\mathrm{kg}$ of live weight gain with rapid infusion of the fish diet and with ingestion of the control diet ; this might be due to urinary losses or to lack of precision in measuring live weight gain.

When both diets were infused slowly, apparent nitrogen digestibility was only slightly less than that observed when the control diet was ingested. It thus seems that the role of abomasal enzymes in protein digestion is relatively moderate. The animals we used were more than one month old, pancreatic proteolytic enzyme secretions were 
quite abundant (Ternouth and Roy, 1973) and their action could at least partly compensate for the reduced action of the gastric secretions. It is also possible that the unfavourable effect of infusion was masked by digestion in the large intestine : contrary to what is observed for lipids, the part of nitrogen which is absorbed in the large intestine increases with the amount of nitrogen escaping digestion in the small intestine (Van Weerden, Huisman and Van Hellemond, 1977 ; Guilloteau et al., 1980a). In our experimental conditions, the nature of the protein had less effect than the gastric emptying rate, but probably this would not be so if the protein substitute used was less digestible than that of the hydrolysed fish ; thus, non-hydrolysed fish protein or that of soya concentrates is less digestible than hydrolysed fish protein (Guilloteau et al., 1977 ; Toullec ef al., 1977), although its gastric emptying rate is slower (Guilloteau et al., 1975, 1979).

Faecal amino acid composition was always close to that observed by Mason, Just and Bech Andersen (1976) for isolated bacteria in pig faeces ( $\chi^{2}$ ranging between 23 and 57), except when calf $B$ was given the control diet by quick infusion $\left(\chi^{2}=135\right)$. Slowing down the arrival of the fish diet in the duodenum thus changed faecal composition very little; the origin of the faecal protein remained primarily bacterial. On the contrary, rapid infusion of the control diet, especially in calf $B$, caused a decrease in the relative proportion of microbial protein (fig. 2). In that case, it was possible to calculate the amino acid composition of the additional undigested protein in relation to ingestion (table 4). This protein was rich in serine, glutamic acid, valine and isoleucine but poor in tyrosine, phenylalanine and arginine; its characteristics do not resemble those of the known proteins in milk, endogenous secretions or digestive tract bacteria. It is probable that special fractions of dietary protein partly escape enzyme digestion in the small intestine and microbial fermentation in the large intestine. These fractions could be mainly peptides containing high amounts of phosphorylated serine of segments 63-69 in the polypeptide chain of $\alpha_{\mathrm{s}_{1}}$ casein, 7-12 in that of $\alpha_{\mathrm{s}_{2}}$ casein, and 14-21 in that of $\beta$ casein ; these peptides, of very similar primary structure and containing 3 or 4 phosphorylated serine residues, 2 glutamic acid residues and 1 isoleucine $\left(\alpha_{\mathrm{S}_{1}}\right)$, valine $\left(\alpha_{\mathrm{S}_{2}}\right)$ or leucine $(\beta)$ residue, are particularly resistent to hydrolysis by endopeptidases and exopeptidases (Mercier, Grosclaude and Ribadeau-Dumas, 1971 ; Brignon et al., 1977). This hypothesis, confirming the studies of Naito and Suzuki (1974), who found phosphopeptides in the distal third of the samll intestine of rats eating casein, does not agree however with the recent observations of Pelissier (personal communication) who has not found any phosphopeptides in the faeces of axenic rats given serine-labelled casein. Moreover, the low level of aromatic and basic amino acids of the additional undigested protein after rapid infusion of the control diet, may be explained by the fact that these amino acids are easily released by pancreatic carboxypeptidases after casein hydrolysis by trypsin and chymotrypsin. An analysis of the ileum digesta probably would have helped to clarify these points (Guilloteau ef al., 1980b).

The study of the free amino acid levels in the jugular blood agrees with the observations of Patureau-Mirand et al. (1974) and Toullec and Patureau-Mirand (1979) concerning the nature of dietary protein. Indeed, the differences in the blood levels of some free amino acids (valine, isoleucine, leucine, tyrosine, phenylalanine, histidine, methionine and glycine) reflected differences in feed composition (taking into account 
supplements). Moreover, blood threonine and lysine levels were higher with the ingested or rapidly infused fish diet than with the rapidly infused control dief; with slow infusion, these levels were lower with the fish than with the control diet, although they were similar in both diets. This suggests that the metabolic utilization of some essential amino acids may be limited when gastric transif is rapid (Patureau-Mirand ef al., 1974 ; Toullec and Patureau-Mirand, 1979) but not when it is slow, which would explain the lower performances obtained with substitute protein even when its digestive utilization is high (Paruelle ef al., 1974). The resemblance between blood free amino acid levels, obtained when the gastric emptying of each diet was simulated, indicates that this simulation and the kinetics of gastric emptying observed when using calves fitted with duodenal re-entrant cannulae (Guilloteau ef al., 1975), were not far from the reality. These results agree with the blood kinetics we found for $\alpha$-amino nitrogen and for lipid after ingestion of the control and fish diets (Toullec, Guilloteau and Coroller, 1979).

In conclusion, the digestion of protein, and especially of lipid and minerals, as well as the metabolic ufilization of amino acids, depends on the length of time these elements stay in the abomasum and the speed at which they arrive in the duodenum. In our experimental conditions, the rate of gastric emplying had more effect than the nature of the protein ; this probably would not be the case with less digestible protein. The rate of gastric emplying likely affects the very young calf more due to lower pancreatic enzyme secretion (Ternouth and Roy, 1973). This would explain, at least in some measure, the lower digestive utilization of food containing protein substitutes.

Reçu en janvier 1981. Accepté en avril 1981.

Résumé. Le remplacement de la poudre de laił écrémé par d'autres sources de protéines dans les aliments d'allaitement augmente la vitesse de l'évacuation gastrique des lipides et des protéines. L'utilisation digestive et métabolique de ceux-ci peut alors être influencée défavorablement du fait de leur temps de contact plus court avec les sécrétions digestives agissant dans la caillette et de leur arrivée plus massive dans le duodénum. Le but de cet essai est d'éfudier les effets respectifs de ces deux facteurs.

Sept veaux préruminants sont munis d'un cathéter introduit dans le duodénum proximal. Ils reçoivent deux aliments ayant des cinétiques d'évacuation gastrique très différentes et dont les protéines proviennent en quasi-totalité de la poudre de lait écrémé (aliment Témoin) ou en majeure partie d'un concentrat de poisson blanc partiellement hydrolysé (aliment Poisson) (tabl. 1). Les laits de remplacement sont soit ingérés par les animaux, soit infusés lentement ou rapidement dans le duodénum de manière à simuler les vitesses d'évacuation gastrique observées précédemment (Guilloteau et al., 1975) pour les matières azotées de deux aliments très voisins de ceux utilisés dans cet essai.

Le fait de court-circuiter la bouche ef la caillette ne semble pas avoir d'incidence importante sur l'état sanitaire des animaux notamment sur la fréquence des diarrhées (fig. 1). La digestibilité apparente de chaque aliment diminue lorsqu'il est infusé dans le duodénum à la vitesse d'évacuation gastrique de ses matières azotées (infusion lente pour l'aliment Témoin, infusion rapide pour l'aliment Poisson) ( $\nmid a b l .2$ ) ; l'infusion à une vitesse supérieure (infusion rapide pour l'aliment Témoin) accroît cet effet ; l'infusion à une vitesse inférieure (infusion lente pour l'aliment Poisson) l'annule. Ceci est plus marqué pour les lipides et les minéraux que pour les matières azotées.

L'infusion lente de l'aliment Poisson a peu d'influence sur la composition en acides aminés des fèces (tabl. 4). En revanche, l'infusion rapide de l'aliment Témoin paraît entraî. 
ner une diminution de la proportion relative des protéines microbiennes au profit de fractions particulières desprotéines du lait (phosphopeptides riches en sérine et en acide glutamique des caséines $\alpha_{\mathrm{s} 1}, \alpha_{\mathrm{s} 2}$ et $\beta$ ).

Les teneurs sanguines en acides aminés libres, mesurées lors de la simulation de l'évacuation gastrique de chaque aliment sont voisines de celles observées lors de l'ingestion (tabl. 5). Avec chacun des deux régimes, ces teneurs sont plus élevées quand l'aliment est infusé rapidement que lorsqu'il est infusé lentement.

En conclusion, le temps de séjour dans la caillette et la vitesse d'arrivée dans le duodénum ont une influence importante sur la digestion des protéines et surtout sur celle des lipides et des minéraux ainsi que sur l'utilisation métabolique des acides aminés.

\section{References}

BELL F. R., 1979. The relevance of the new knowledge of gastrointestinal hormones to veterinary science. Vet. sci. Commun., 2, 305-314.

BLAXTER K. L., WOOD W. A., 1953. Some observations on the biochemical and physiological events associated with diarrhoea in calves. Vet. Rec., 50, 889-892.

BRIGNON G., RIBADEAU-DUMAS B., MERCIER J. C., PELISSIER J. P., DAS B. C., 1977. Complete amino-acid sequence of bovine $\alpha_{\mathrm{s}_{2}}$ casein. FEBS Leffers, 76, 274-279.

FAKAMBI L., FLANZY J., FRANÇOIS A. C., 1969. Compétition in vivo entre acides gras et phosphore pour la formation de composés insolubles de calcium. C. R. Acad. Sci. Paris, sér. D, 269, 22332235.

GUÉGUEN L., MATHIEU C. M., 1962. L'utilisation des éléments minéraux de la ration par le veau. I. Influence du régime alimentaire. Ann. Zootech., 11, 115-134.

GUILLOTEAU P., PARUELLE J. L., TOULLEC R., MATHIEU C. M., 1975. Ufilisation des protéines par le veau préruminant à l'engrais. III. - Influence du remplacement des protéines du lait par celles du poisson sur la vidange stomacale. Ann. Zootech., 24, 243-253.

GUILLOTEAU P., PATUREAU-MIRAND P., SAUVANT D., TOULLEC R., 1980a. Digestion of protein in the distal ileum and the terminal gut of the preruminant calf. In $3 r d$ E.A.A.P. Symp. on Protein metabolism and nutrition, 5-9 mai, Braunschweig (Allemagne).

GUILLOTEAU P., PATUREAU-MIRAND P., TOULLEC R., PRUGNAUD J., 1980b. Digestion of milk protein and methanol-grown bacteria protein in the preruminant calf. II. - Amino-acid composition of ileal digesta and faeces and blood levels of free amino-acids. Reprod. Nutr. Dévelop., 20, 615-629.

GUILLOTEAU P., TOULLEC R., CULIOLI J., LE DOUARON D., 1977. Utilisation des protéines par le veau préruminant à l'engrais. $V$. - Utilisation digestive des protéines du poisson, du soja et de la féverole. Ann. Zootech., 26, 15-28.

GUILLOTEAU P., TOULLEC R., PATUREAU-MIRAND P., 1979. Influence de la vitesse d'évacuation gastrique des protéines ef des lipides sur l'utilisation digestive chez le veau préruminant. Ann. Biol. anim. Bioch. Biophys., 19, 955-958.

GUILLOTEAU P., TOULLEC R., SAUVANT D., PARUELLE J. L., 1979. Utilisation des protéines par le veau préruminant à l'engrais. VII. - Influence du remplacement des protéines du lait par celles du soja ou de la féverole sur l'évacuation gastrique. Ann. Zootech., 28, 1-17.

MASON V. C., JUST A., BECH-ANDERSEN S., 1976. Bacterial activity in the hindgut of pigs. 2. Its influence on the apparent digestibility of nitrogen and amino-acids. Z. Tierphysiol. Tierernährg Fuffermitfelkde., 36, 310-324.

MERCIER J. C., GROSCLAUDE F., RIBADEAU-DUMAS B., 1971. Structure primaire de la caséine $\alpha_{\mathrm{S}_{1}}$ bovine. Séquence complète. Eur. J. Bioch., 23, 41-51.

NAITO H., SUZUKI H., 1974. Further evidence for the formation in vivo of phosphopeptide in the infestinal lumen from dielary $\beta$-casein. Agri. biol. Chem., 38, 1543-1545.

PARUELLE J. L., TOULLEC R., MATHIEU C. M., 1973. Utilisation digestive d'aliments d'allaitement contenant des lactosérums de différentes qualités par le veau préruminant à l'engrais. Ann. Zoofech., 22, 237-242. 
PARUELLE J. L., TOULLEC R., PATUREAU-MIRAND P., MATHIEU C. M., 1974. Utilisation des protéines par le veau préruminant à l'engrais. II. - Utilisation des protéines de poisson et influence de l'addition d'un complexant du fer. Ann. Zootech., 23, 519-536.

PATUREAU-MIRAND P., TOULLEC R., GUILLOTEAU P., PION R., 1977 . Influence de la nature des protéines alimentaires sur la composition en acides aminés des fèces du veau préruminant. Ann. Biol. anim. Bioch. Biophys., 17, 71-83.

PATUREAU-MIRAND P., TOULLEC R., PARUELLE J. L., PRUGNAUD J., PION R., 1974. Influence de la nature des matières azotées des aliments d'allaitement sur l'amino-acidémie du veau préruminant. I. - Matières azotées du lait, du lactosérum, du poisson et des levures d'alcanes. Ann. Zoofech., 23, 343-358.

TERNOUTH J. H., ROY J. H. B., 1973. The effect of diet and feeding technique on digestive function in the calf. Ann. Rech. vétér., 4, 19-30.

TOULLEC R., COROLLER J. Y., PATUREAU-MIRAND P., 1977. Utilisation des protéines par le veau préruminant à l'engrais. VI. - Influence de la solubilité des protéines de maïs et de poisson sur leur utilisation digestive. Ann. Zoofech., 26, 523-532.

TOULLEC R., FELINSKI L., 1971. Hydrolyse des triglycérides à chaîne longue dans la caillette du veau préruminant. Ann. Biol. anim. Bioch. Biophys., 11, 315-317.

TOULLEC R., FLANZY J., RIGAUD J., 1968. Dosage des lipides des fèces : extraction séparée, importance et composition en acides gras des lipides non saponifiés et de ceux des complexes insolubles. Ann. Biol. anim. Bioch. Biophys., 8, 281-289.

TOULLEC R., GUILLOTEAU P., COROLLER J. Y., 1979. Influence de la cinétique d'évacuation gastrique de l'aliment sur l'absorption chez le veau préruminant. Ann. Biol. anim. Bioch. Biophys., 19, 729-732.

TOULLEC R., PATUREAU-MIRAND P., 1979. Influence du procédé d'hydrolyse des protéines de poisson sur leur utilisation par le veau de boucherie. Comparaison avec les protéines de lait et celles de soja. Ann. Zoofech., 28, 407-422.

VAN WEERDEN E. J., HUISMAN J., VAN HELLEMOND K. K., 1977. Verteringsfysiologisch onderzoek. Enkele nitkomsten ten aanzien van het verterings proces in het maagdarmkanaal van het mestkalf. Landbouwkundig Tijdsch., 89, 217-224. 